\title{
Peran Orang Tua dalam Meningkatkan Motivasi Belajar Siswa Sekolah Dasar di Kecamatan Bantaran Kabupaten Probolinggo
}

\author{
Ari Susandi1, Irmawati Apriliana², Ningsih³, Reza Hilmy Luayyin4 \\ STAI Muhammadiyah Probolinggo \\ Surel: pssandi87@gmail.com
}

\begin{abstract}
Abstrak
Tujuan penelitian ini untuk mengetahui peran orang tua dalam meningkatkan motivasi belajar siswa dalam hal ini tentu saja sebagai orang tua memiliki peran yang sangat besar dalam proses yang dilalui oleh anak dalam menunjang motivasi belajarnya, Penelitian ini menggunakan pendekatan kualitatif sering dideskripsikan sebagai penelitian yang mempublikasikan fenomena serta perilaku sosial sebagaimana yang ada (in natural setting) dan juga sesuai dengan fakta dan juga media online yang ada kemudian dipahami dan setelah itu lalu mendapatkan data dan informasi untuk dapat ditambahkan dan dikaji melalui catatan kecil kemudian menjadi analisa yang ada sehingga didapatkan suatu kajian yang relevan dan akurat. Populasi dan sampel yang digunakan dalam penelitian ini merupakan 5 siswa yang terdiri dari kelas IV Hingga kelas V MI Miftahul Arifin dan 5 orang tua wali murid serta guru kelas. Istrumen pengumpulan data yang dilakukan adalah dengan menggunakan quesioner yang di kirimkan ke masing-masing siswa dengan berbagai jenis pertanyaan yang relevan serta juga obsevasi lapangan dalam bentuk wawancara terbuka dalam kunjungan ke rumah siswa, hasil penelitian menujukkan bahwa Pendidikan orang tua dan kedekatan orang tua dengan anak sangat berpengaruh terhadap motivasi belajarnya dilihat dari hasil kuesioner dan wawancara yang telah dilakukan oleh peneliti dengan orang tua dan anak.
\end{abstract}

Kata Kunci: Peran Orang Tua, Motivasi Belajar, Siswa Sekolah Dasar

\begin{abstract}
The purpose of this study was to determine the role of parents in increasing students' learning motivation in this case, of course, as parents have a very large role in the process that children go through in supporting their learning motivation. This study uses a qualitative approach, often described as research that publishes phenomena and social behavior as it exists (in natural setting) and also in accordance with the facts and also existing online media then understood and after that then get data and information to be added and reviewed through small notes then become an existing analysis so that a study is obtained that relevant and accurate. The population and samples used in this study were 5 students consisting of class IV to class V MI Miftahul Arifin and 5 parents, guardians of students and class teachers. The data collection instrument used was a questionnaire sent to each student with various types of relevant questions as well as field observations in the form of open interviews during visits to students' homes, the results of the study showed that the education of parents and the closeness of parents with their children very influential on the motivation to learn
\end{abstract}


seen from the results of the questionnaire and interviews that have been conducted by researchers with parents and children.

Keywords: Role of Parents, Learning Motivation, Elementary School Students

\section{A. PENDAHULUAN}

Pendidikan saat ini sedang mengalami hambatan yang sangat besar dengan adanya pandemi covid-19 yang tak kunjung mereda, kegiatan proses belajar mengajar yang dilakukan di sekolah memiliki banyak kendala dan juga harus mengikuti aturan yang telah disepakati oleh pemerintah. Salah satunya pembelajaran berbasis online dan diharuskan untuk setiap lembaga yang terdampak covid-19, tidak mengadakan pembelajaran secara tatap muka karena untuk mengurangi resiko penularan virus yang sangat mematikan itu. Pendidikan merupakan unsur dalam perubahan pola tingkah laku serta etika dalam diri seseorang menuju arah yang terstruktur yang diaplikasikan dalam proses pembelajaran, bertujuan mengembangkan intelegensi dan etika dalam perilaku individu yang terbentuk melalui berbagai proses berdasarkan pada norma yang berlaku. ${ }^{1}$ Caranya yakni melalui mengkonseptualisasikan perkembangan manusia dengan interaksi dua arah, antara individu dan berbagai sistem yang berhubungan dengan lingkungan, sekolah, komunitas, dan masyarakat. Dengan demikian, karakteristik individu dipengaruhi oleh banyak hubungan dengan teman sebaya, keluarga, guru, tetangga. ${ }^{2}$

Keluarga adalah lingkungan sosial inti anak. Ia merupakan kelompok sosial terkecil yang terdiri atas ayah, ibu, dan anak. Hubungan sosial diantara anggota keluarga relatif tetap serta atas ikatan darah, perkawinan dan/atau adopsi, yang dijiwai oleh rasa tanggung jawab dalam memelihara, merawat, dan melindungi anak. Sehingga ayah dan ibu dalam keluarga dapat dikatakan sebagai orang tua. Peran orang tua bagi pendidikan anak adalah memberi dasar pendidikan, sikap, dan ketrampilan dasar, seperti pendidikan agama, budi pekerti, sopan santun estetika, kasih sayang, dan rasa aman dalam menyelesaikan dan mengikuti kehidupan yang dijalaninya. ${ }^{3}$ Di lingkungan keluarga inilah anak mendapatkan pendidikan yang utama. Tugas utama keluarga ialah sebagai pondasi bagi pendidikan moral dan karakter dari anak. Interaksi yang intens antara anak dengan orang dewasa yang memiliki suatu hubungan khusus terhadap anak dapat memberikan pengaruh yang baik, signifikan bagi tumbuh kembang sang anak. $^{4}$

Dalam observasi awal yang telah peneliti lakukan pada peserta didik tanggal 1617 Januari 2020 di MI Miftahul Arifin Kropak Kecamatan Bantaran, Kabupaten

1 A Susandi, "Pendidikan Life Skills Dalam Penanaman Nilai-Nilai Agama Islam Di Sekolah Dasar," AlInsyiroh: Jurnal Studi Keislaman Vol. 6 No. (2020).

2 S Swearer, S. M., \& Hymel, "Understanding the Psychology of Bullying: Moving toward a SocialEcological Diathesis-Stress Model," American Psychologist Vol. 70 No (2015).

${ }^{3}$ A. F. H. S Fatonah, "Hubungan Pola Asuh Orang Tua Dengan Perilaku," Ibriez Volume. 5 (2020).

${ }^{4}$ M. F Iftitah, S. L., \& Anawaty, "Peran Orang Tua Dalam Mendampingi Anak Di Rumah Selama Pandemi Covid-19," JCE (Journal of Childhood Education) Vol. 4 No. (2020). 
Probolinggo terdapat 5 siswa yang memiliki prestasi belajar yang menurun dan selalu dalam setiap proses kegiatan belajar mengajar tidak pernah fokus. Di samping itu, jika memiliki pekerjaan rumah tidak pernah dikerjakan sama sekali dan sering bermain dengan teman yang sama-sama memiki kebiasaan tersebut, akibatnya nilai hasil belajar peserta didik yang hampir keseluruhan mata pelajaran jauh dari KKM, bahkan pendidik sudah beberapa kali memberikan pendampingan di sekolah tetap saja belum menunjukkan perubahan yang signifikan.

Melihat persoalan di atas, penguatan motivasi dan minat belajar siswa dalam menggali potensi yang dimiliki harus diajarkan sejak dini, dalam hal ini pendidik harus ekstra dalam memberikan berbagai jenis pilihan dalam sistem pembelajaran, namun tidak bisa dipungkiri juga peran serta orang tua memang juga harus lebih maksimal dikarenakan kegiatan belajar mengajar yang menggunakan media informasi dan komunikasi lebih rentan dengan berbagai resiko, dan peserta didik dalam tingkat pendidikan dasar perlu adanya edukasi selain dengan pendidik yang mengajar juga dari orang tua yang harus sebisa mungkin mendampingi anaknya dalam proses pembelajaran secara online dan harus bisa menyeimbangkan dengan waktu dengan aktivitas lain seperti bekerja.

Menyiapkan generasi muda untuk mampu menyelesaikan berbagai permasalahan yang dihadapi oleh peserta didik dalam hal ini juga prestasi belajar peserta didik juga menjadi prinsip yang kuat dalam mencapai motivasi belajar yang baik karena ketika motivasi belajar peserta didik ini semakin berpegaruh terhadap prestasi belajar siswa dan kita sebagai orang tua harus memahami berbagai persoalan lingkungan juga akan bisa mempengaruhi moralitas peserta didik untuk dapat mengedukasi diri dalam proses belajar serta juga berkelanjutan dengan nilai-nilai moral telah menjadi semacam lampu merah semua pihak, lembaga pendidikan, orangtua, negara, dan lembaga kemasyarakatan dan sinergi bagi pengembangan pendidikan dalam membentuk karakter ekologis bagi siswa. ${ }^{5}$

\section{B. METODE PENELITIAN}

Metode penelitian yang digunakan adalah analisis deskriptif kualitatif dengan menampilkan pembaharuan penelitian maupun analisis dari berbagai pendapat dalam artikel ilmiah yang sudah ada dalam jurnal. Penelitian kualitatif sering dideskripsikan sebagai penelitian yang mempublikasikan fenomena serta perilaku sosial sebagaimana yang ada (in natural setting) dan juga sesuai dengan fakta dan juga media online yang ada kemudian dipahami dan setelah itu lalu mendapatkan data dan informasi untuk dapat ditambahkan dan dikaji melalui catatan kecil kemudian menjadi analisa yang ada sehingga didapatkan suatu kajian yang relevan dan akurat. Populasi dan sampel yang digunakan dalam penelitian ini merupakan 5 siswa yang terdiri dari kelas IV Hingga kelas V MI Miftahul Arifin dan 5 orang tua/wali murid serta guru kelas. Instrumen

\footnotetext{
${ }^{5}$ M Muhaimin, “Pendidikan Lingkungan Hidup Dalam Perspektif Islam,” Syaikhuna: Jurnal Pendidikan Dan Pranata Islam Vol. 11 No (2020).
} 
pengumpulan data yang dilakukan adalah dengan menggunakan kuesioner yang di kirimkan ke masing-masing siswa dengan berbagai jenis pertanyaan yang relevan serta juga obsevasi lapangan dalam bentuk wawancara terbuka dalam kunjungan kerumah siswa.

C. HASIL DAN PEMBAHASAN

Tabel 1. Hasil Wawancara Siswa

\begin{tabular}{|l|l|}
\hline \multicolumn{1}{|c|}{ Nama Narasumber } & \multicolumn{1}{c|}{ Alamat } \\
\hline Ahmad Reza Kelas 5 & $\begin{array}{l}\text { Desa kropak kecamatan Bantaran kabupaten } \\
\text { Probolinggo }\end{array}$ \\
\hline Senimakelas 5 & $\begin{array}{l}\text { Desa Kramat Agung Kecamatan Bantaran Kabupaten } \\
\text { Probolinggo }\end{array}$ \\
\hline Muhammad Shohibkelas 4 & $\begin{array}{l}\text { Desa kropak kecamatan Bantaran kabupaten } \\
\text { Probolinggo }\end{array}$ \\
\hline Syaif Ali Khan kelas 5 & $\begin{array}{l}\text { Desa Kramat Agung Kecamatan Bantaran Kabupaten } \\
\text { Probolinggo }\end{array}$ \\
\hline $\begin{array}{l}\text { Ahmad KanzulKaromi Kelas } \\
4\end{array}$ & $\begin{array}{l}\text { Desa Kramat Agung Kecamatan Bantaran Kabupaten } \\
\text { Probolinggo }\end{array}$ \\
\hline
\end{tabular}

Tabel 2. Hasil Wawancara Orang tua

\begin{tabular}{|l|l|}
\hline \multicolumn{1}{|c|}{ Nama Narasumber } & \multicolumn{1}{c|}{ Alamat } \\
\hline Bapak Salim & $\begin{array}{l}\text { Desa kropak kecamatan Bantaran kabupaten } \\
\text { Probolinggo }\end{array}$ \\
\hline Bapak Ilham Sugiarto & $\begin{array}{l}\text { Desa Kramat Agung Kecamatan Bantaran Kabupaten } \\
\text { Probolinggo }\end{array}$ \\
\hline Bapak Selamet & $\begin{array}{l}\text { Desa kropak kecamatan Bantaran kabupaten } \\
\text { Probolinggo }\end{array}$ \\
\hline Ibu Kama & $\begin{array}{l}\text { Desa Kramat Agung Kecamatan Bantaran Kabupaten } \\
\text { Probolinggo }\end{array}$ \\
\hline Ibu Rohma & $\begin{array}{l}\text { Desa Kramat Agung Kecamatan Bantaran Kabupaten } \\
\text { Probolinggo }\end{array}$ \\
\hline
\end{tabular}

Hasil wawancara yang dilakukan oleh peneliti kepada peserta didik dengan peserta didik pertama yang bernama Ahmad Reza Kelas 5 alamat di desa Kropak, kecamatan Bantaran, kabupaten Probolinggo pada tanggal 20 Desember 2020 pukul 10.00 WIB yang merupakan peserta didik di MI Miftahul Arifin dan juga orang tua bapak Salim memperoleh hasil bahwa pendampingan orang tua di rumah masih sangat kurang, anak cenderung jarang ditanyai bagaimana aktivitas di sekolah maupun di lingkungan tempat mereka tinggal, dan orang tua cenderung sibuk dengan urusan pekerjaan rumah dan aktivitas mereka sendiri lalu terkadang juga mereka hanya belajar dengan tetangga. Selain itu orang tua yang memang terletak di desa dan belum begitu mengerti tentang dunia pendidikan dan cenderung kurang dalam pemahaman 
tentang pendidikan inilah yang penanaman untuk meraih prestasi yang tinggi dan pendidikan ke jenjang yang lebih tinggi masih.

Ini membuktikan bahwa memang masih minimnya tingkat pendidikan serta orang tua siswa ini tidak telaten dalam memberikan support untuk proses keberlangsungan pendidikan dan cita-cita yang ada dalam diri yang mengakibatkan anak jadi kurang semangat belajar dan cenderung bermain terus-terusan di luar rumah karena merasa tidak ada pendekatan dan pengawasan terkait dengan sekolah mereka dan belajar mereka dan memang lingkungan di tempat mereka tinggal masih sangat sedikit yang melanjutkan di perguruan tinggi dan itupun juga karena motivasi dan dukungan dari orang tua mereka.

Hal ini menunjukkkan bahwa sebaik apapun seorang guru dalam merancang dan mendampingi suatu program pembelajaran, kiranya tidak akan dapat secara optimal mewujudkan ketercapaian kompetensi yang diharapkan apabila tidak didukung oleh teknologi dan peran dari orang tua peserta didik dan juga keterlibatan pihak-pihak yang dirasa penting untuk peserta didik. ${ }^{6}$ Perilaku peserta didik yang harus terus dilakukan pendampingan agar tidak menyimpang dari akhlak pendekatan interpersonal sehingga perlu pendekatan interpersonal dan komunikasi yang baik antar individu baik di lingkungan maupun sekolah. ${ }^{7}$ Wawancara yang dilakukan oleh peneliti kepada peserta didik kedua yang bernama Senima kelas 5 alamat di desa Kramat Agung, Kecamatan Bantaran Kabupaten Probolinggo pada tanggal 21 Desember 2020 pukul 10.45 Wib yang merupakan peserta didik di sekolah MI Miftahul Arifin dan juga orang tua peserta didik bernama bapak Ilham Sugiarto memperoleh hasil bahwa memang orang tua dari peserta didik ini kurang dalam memantau anaknya dikarenakan kesibukan pekerjaan yang tidak dapat ditinggalkan selain itu juga hanya belajar dengan sepupu, dan setiap pulang sekolah dan berangkat sekolah pun hanya sekedar bersalaman dan berangkat jarang ditanya apakah ada pekerjaan rumah dari pendidik selain itu juga memang orang tua yang hidup di desa dan belum begitu mengerti tentang dunia pendidikan dan cenderung kurang dalam pemahaman tentang pendidikan. Kenakalan remaja yang cukup mengkhawatirkan tersebut semakin hari semakin meningkat. Kian terpuruknya akhlak warga negara merupakan keprihatinan semua elemen masyarakat itu kembali, maka peran sebagai orang tua sangat di butuhkan untuk dapat memberikan motivasi dalam diri anak untuk terhindar dari sikap yang tercela. ${ }^{8}$ Wawancara yang dilakukan oleh peneliti kepada peserta didik ketiga yang bernama Muhammad Shohib kelas 4 alamat di desa Kropak, Kecamatan Bantaran Kabupaten Probolinggo pada tanggal 22 Desember 2020 pukul 10.15 Wib yang merupakan peserta didik di sekolah MI Miftahul Arifin dan juga orang tua peserta didik

\footnotetext{
${ }^{6}$ Syamsuar and Reflianto, "Pendidikan Dan Tantangan Pembelajaran Berbasis Teknologi Informasi Di Era Revolusi Industri 4.0.," ETECH Vol. 6 No. (2019).

${ }^{7}$ Susandi, "Pengajaran Guru Pendidikan Dasar Di Era Millenial Dalam Membentuk Moral Siswa."

8 Munirah, "Implementasi Pendidikan Islam Dalam Keluarga Muslim Pesisir Pada Anak Nelayan Cambaya Paotere Kecamatan Ujung Tanah Kota Makasar," Auladuna: Jurnal Pendidikan Dasar Islam Vol. 6 No. (2019).
} 
bernama Bapak Selamet memperoleh hasil bahwa orang tua peserta didik ini yang pekerjaanya sebagai petani dan juga serabutan dan ibu juga mengurus rumah tangga kurang memberikan perhatian kepada anaknya mereka jarang sekali berinteraksi tentang bagaimana proses pembelajaran di sekolah dan bagaimana keadaan guru yang mengajar serta pekerjaan rumah dan nilai hasil dari mereka selama belajar di sekolah, dan anaknya hanya belajar dengan tetangga dan saudara itupun juga jarang di lihat dan didampingi oleh orang tua peserta didik ini.

Selain itu juga memang orang tua yang hidup di desa dan belum begitu mengerti tentang dunia pendidikan dan cenderung kurang dalam pemahaman tentang pendidikan inilah yang penanaman untuk akan dalam meraih prestasi yang tinggi dan pendidikan ke jenjang yang lebih tinggi. Peran orang tua dalam hal ini memang dibutuhkan untuk mengetahuai kelemahan fisik, rendah diri, pasif dalam kegiatan sosial, rasa malu, depresi, kecemasan, kurangnya keterampilan sosial dan teman sehingga mengetahui apa yang diinginkan oleh anaknya. ${ }^{9}$ Jika usia dewasa anak tidak mudah mengalami depresi bahkan bisa menjadi stress dengan motivasi belajar yang kuat. Depresi bukan saja dialami oleh orang dewasa tetapi anak-anak juga bisa mengalami depresi yang tidak mengenal kelas sosial untuk itu memang sejak dini pendampingan belajar siswa sangat diperlukan. ${ }^{10}$

Wawancara yang dilakukan oleh peneliti kepada peserta didik ke empat yang bernama Syaif Ali Khan kelas 5 alamat di desa Kramat Agung, Kecamatan Bantaran, Kabupaten Probolinggo pada tanggal 23 Desember 2020 pukul 09.45 Wib yang merupakan peserta didik di sekolah MI Miftahul Arifin dan juga orang tua peserta didik bernama ibu Kama memperoleh hasil, bahwa kesibukan orang tua yang bekerja sebagai seorang serabutan dan juga bertani terkadang mereka kerja pagi hingga larut sore kadang pun bertegur sapa sangat jarang karena faktor kelelahan. Akhirnya orang tua pun kurang sadar dengan potensi yang dimiliki oleh anaknya di sekolah. Dalam hal ini memang orang tua juga harus mampu memberikan penguasaan bahasa sebagai sistem pilihan untuk mengkomunikasikan dengan baik terhadap anaknya mengekspresikan pengalamannya tentang dunia, berinteraksi dengan orang lain dan membuat pesan yang koheren dan bermanfaat. ${ }^{11}$ Wawancara yang dilakukan oleh peneliti kepada peserta didik kelima yang bernama Ahmad Kanzul Karomi kelas 4 alamat di desa Kramat Agung, Kecamatan Bantaran, Kabupaten Probolinggo pada tanggal 24 Desember 2020 pukul 13.45 Wib yang merupakan peserta didik di sekolah MI Miftahul Arifin dan juga orang tua peserta didik bernama Ibu Rohma memperoleh hasil bahwa memang orang tua dari peserta didik ini kurang dalam memantau anaknya dikarenakan kesibukan pekerjaan yang tidak dapat ditinggalkan selain itu juga hanya

${ }^{9}$ C. Efobi, A., \& Nwokolo, "Relationship between Parenting Styles and Tendency to Bullying Behaviour among Adolescents," Journal of Education \& Human Development Vol. 3 No. (2014).

10 A Dirgayunita, "Depresi: Ciri, Penyebab Dan Penangannya," Journal An-Nafs: Kajian Penelitian Psikologi Vol. 1 No. (2016).

11 Nurlaelawati I and Gunawan, "Recontextualising Genre-Based Pedagogy in Indonesian Context: A Case of Preservice Teachers." 
belajar dengan sepupu dan guru les, dan setiap pulang sekolah dan berangkat sekolah pun hanya sekedar berjabat tangan dan berangkat terkadang jarang ditanya apakah ada pekerjaan rumah dari pendidik selain itu juga memang orang tua yang hidup di desa dan belum begitu mengerti tentang dunia pendidikan.

Ada beberapa faktor penting yang harus diperhatikan, agar sistem pendidikan jarak jauh menjadi efektif dan dapat menjalin interaksi dengan peserta didik dan juga peran dari lingkungan. Selain itu, kapabilitas yang mengatur cara bagaimana peserta didik dapat mengelola belajarnya juga di perlukan, sehingga anak mampu untuk menyesuaikan dengan apa yang dimiliki dalam hal ini pula kompetensi dan kognisi anak akan dapat berjalan sesuai dengan pikiran mereka. ${ }^{12}$

Keluarga merupakan tujuan utama seorang anak memperoleh pengasuhan dan penguatan baik secara jasmani maupun rohani, sebagai orang tua tentu saja harus mampu memahami karakteristik dan memberikan dukungan penuh terhadap segala sesuatu yang berhubungan dengan dunia anak dalam menempuh pendidikan di tingkat sekolah dasar hingga pada pendidikan yang lebih tinggi, motivasi dan dukungan orang tua sangat berpengaruh besar terhadap psikologi dan perkembangan ada pada masa Pendidikan dalam hal ini motivasi anak dalam mengikuti setiap proses kegiatan pembelajaran baik di sekolah maupun di lingkungan masyarakat.

\section{PENUTUP}

\section{Simpulan}

Di tingkat pendidikan dasar pendidik harus benar-benar melakukan pendampingan secara efektif dan berkala, dikarenakan penanaman jatidiri pada peserta didik dimulai sejak pendidikan dasar dimana hal ini sangat berpengaruh meningkatkan mutu dan standar pendidikan nasional, maka berbagai usaha dan peraturan untuk menyeragamkan pendidikan nasional dengan bergulirnya regulasi sistem pembelajaran dan harus dilaksanakan dengan maksimal. Selain itu, peran orang tua tidak kalah penting dalam posisi ini sebab lingkungan utama tempat mereka tumbuh berkembang dan belajar mengaktualsisasikan diri adalah orang tua.

Oleh sebab itu, orang tua dengan ragam latar belakang yang ada seyogyanya mengupgrade diri dalam berkomunikasi dan melakukan pendampingan terhadap perlakuan anak, baik dalam pendidikan maupun di luar pendidikan. Terdapat dua pendekatan dalam upaya ini, pertama yakni pendekatan interpersonal dimana komunikasi dari dua belah pihak (orang tua dan anak) harus sebangun sejalan dalam berinteraksi. Kedua, intrapersonal yakni penyadaran terhadap diri anak apabila dalam perlakukannya masih ditemukan kekurangan. Harapan dari pendekatan ini, adalah sedari kecil anak diberi pengertian sehingga kedepan dapat berperilaku yang lebih baik.

12 U Prasetiya, B., Hidayah, “Hubungan Gaya Kognitif Dan Motivasi Berprestasi Dengan Hasil Belajar PAI.," BELAJEA: Jurnal Pendidikan Islam Vol. 4 No. (2019). 


\section{E. DAFTAR PUSTAKA}

Dirgayunita, A. “Depresi: Ciri, Penyebab Dan Penangannya." Journal An-Nafs: Kajian Penelitian Psikologi Vol. 1 No. (2016).

Efobi, A., \& Nwokolo, C. "Relationship between Parenting Styles and Tendency to Bullying Behaviour among Adolescents." Journal of Education \& Human Development Vol. 3 No. (2014).

Fatonah, A. F. H. S. "Hubungan Pola Asuh Orang Tua Dengan Perilaku." Ibriez Volume. 5 (2020).

Iftitah, S. L., \& Anawaty, M. F. "Peran Orang Tua Dalam Mendampingi Anak Di Rumah Selama Pandemi Covid-19.” JCE (Journal of Childhood Education) Vol. 4 No. (2020).

Muhaimin, M. "Pendidikan Lingkungan Hidup Dalam Perspektif Islam." Syaikhuna: Jurnal Pendidikan Dan Pranata Islam Vol. 11 No (2020).

Muhaimin, Muhaimin. "Pendidikan Lingkungan Hidup Dalam Perspektif Islam." Syaikhuna: Jurnal Pendidikan Dan Pranata Islam 11, no. 1 (2020): 64-78. https://doi.org/10.36835/syaikhuna.v11i1.3844.

Munirah. "Implementasi Pendidikan Islam Dalam Keluarga Muslim Pesisir Pada Anak Nelayan Cambaya Paotere Kecamatan Ujung Tanah Kota Makasar.” Auladuna: Jurnal Pendidikan Dasar Islam Vol. 6 No. (2019).

- - - "Implementasi Pendidikan Islam Dalam Keluarga Muslim Pesisir Pada Anak Nelayan Cambaya Paotere The Implementation Of Islamic Education In Coastal Muslim Families Towards Th E Fishermen ' S Children At Cambaya Paotere of Ujung Tanah" 6, no. 1 (2019): 26-37.

Nurlaelawati I, Sri Lengkanawati, and Wawan Gunawan. "Recontextualising GenreBased Pedagogy in Indonesian Context : A Case of Preservice Teachers" 12, no. 2 (2020): 80-91. https://doi.org/10.17509/ije.v12i2.23394.

Prasetiya, B., Hidayah, U. "Hubungan Gaya Kognitif Dan Motivasi Berprestasi Dengan Hasil Belajar PAI." BELAJEA: Jurnal Pendidikan Islam Vol. 4 No. (2019).

Susandi, A. "Pendidikan Life Skills Dalam Penanaman Nilai-Nilai Agama Islam Di Sekolah Dasar." Al-Insyiroh: Jurnal Studi Keislaman Vol. 6 No. (2020).

Susandi, Ari. "Pengajaran Guru Pendidikan Dasar Di Era Millenial Dalam Membentuk Moral Siswa." Conciencia 19, no. 2 (2019): 85-98. https://doi.org/10.19109/conciencia.v19i2.4405.

Swearer, S. M., \& Hymel, S. "Understanding the Psychology of Bullying: Moving toward a Social-Ecological Diathesis-Stress Model.” American Psychologist Vol. 70 No (2015).

Syamsuar, and Reflianto. "Pendidikan Dan Tantangan Pembelajaran Berbasis Teknologi Informasi Di Era Revolusi Industri 4.0." ETECH Vol. 6 No. (2019). 